\title{
Why Students in Secondary Schools Choose not to do Physics? Implications For Policy and Practice in Developing Countries
}

\author{
Dr. Telima Adolphus, \\ Department of Science Education Rivers State \\ University Nkpolu-Oroworokwo, Port Harcourt, Nigeria
}

Doi:10.19044/esj.2019.v15n34p103 URL:http://dx.doi.org/10.19044/esj.2019.v15n34p103

\begin{abstract}
This study investigated the low popularity of physics among secondary school students in Rivers State, Nigeria. One outcome of this situation is concern and interest in effective teaching and learning in the subject in Nigeria. A mixed methods research design was adopted for the study. The study found that teachers' qualities and resource availability and utilization significantly influence students' physics enrolment. Also, there was no significant difference in the correlations of teacher and resource factors with enrolment by gender. To boost students' interest in physics, the study recommended amongst others, that teachers present content in ways that connect physics ideas to the everyday experiences of students and that, policy makers should consider making the study of science compulsory in all classes in secondary schools with the introduction of 'science for arts' for the nonscience oriented students.
\end{abstract}

Keywords: Developing Countries, Physics Uptake, Post-Compulsory Secondary Physics, Resources

\section{Introduction}

Physics as the branch of science that is concerned with the nature and properties of matter is relevant to the pursuant of many courses such as medicine, pharmacy, all areas of engineering, applied mathematics, space science and information and communication technology. McCall (2007) upheld this view when she maintained that physics, alongside other sciences such as mathematics, chemistry and biology, is a core part of the pharmacy curriculum in most universities. Despite the relevance of Physics and Physics education, the teaching and learning of physics is still confronted with several challenges. There has been a growing concern about the teaching and learning of science subjects and particularly physics in schools, in most countries of 
the world (Williams, Stanisstreet, Spall, Boyes \& Dickson, 2003; Angell, Guttersrud, Henriksen \& Isnes, 2004).

Studies on the state of teaching and learning of sciences in Nigeria have shown that most students learn by rote with little or no engagement in science classes, as most teachers find it difficult to utilize skills acquired during their training in their lesson delivery (Ogunmade, 2005). In Nigeria, that all is not well in the teaching and learning of Physics, in particular, is captured in the curriculum document which states that:

"physics is crucial for effective living in the modern age of science and technology. Given its application in industry and many other professions, it is necessary that every student is given an opportunity to acquire some of its concepts, principles and skills. Unfortunately, the teaching and learning of physics has been fraught with challenges which prevent many students from performing well in external examinations" (Federal Ministry of Education 2009:ii).

The statement above shows that the curriculum developers acknowledged the relevance of knowledge of physics and desire that most students reasonably get involved in the study of the subject, and that teaching and learning associated problems have discouraged young people from performing well in the subject.

Generally in the literature, the challenge of the effective teaching and learning of physics and sciences has been attributed to the nature of the subject, which appears to have a high difficulty perception, a shortage of qualified teachers, inadequate teaching facilities and a perceived irrelevance of some of the content to the everyday experience of learners (Keller, Neumann \& Fischer, 2017; FME, 2009; Angell, et al., 2004; Williams, et al., 2003; Freedman, 1996). Freedman (1996) noted that "the dominant public perception of Physics is that it is tedious, abstract and fundamentally irrelevant" (p.314); students tend to be interested and motivated in learning subjects that make them link classroom experiences with situations they encounter in the real world around them and outside the school environment. Similarly, Keller, et al., (2017) reported that "secondary school students not only perceive physics as a difficult and demanding subject,... but also show considerable lack of interest in the subject" (p.587).

In an attempt to make the curriculum relevant and appropriate in its content and context, and to address the challenges of effective teaching and learning of physics in Nigeria, the general objectives of the physics curriculum were stated as follows:

1. provide basic 'literacy' in physics for functional living in the society; 2. acquire basic concepts and principles of physics as a preparation for further studies; 
3. acquire essential scientific skills and attitudes as a preparation for technological application of physics; and

4. $\quad$ stimulate and enhance creativity (FME, 2009:ii).

For students to acquire 'basic concepts', 'essential skills' and 'attitudes' for technological application and to stimulate creativity, it is important that they get involved with hands-on activities with adequate resources provided. The curriculum has made clear learners' and teachers' activities specifically for the various lessons and concepts in the curriculum. Whether teachers actually implement the curriculum and have teaching and learning resources to teach physics is of interest in this study.

The challenge of effective delivery and learning of science is also closely followed by the problem of low enrolment. In Nigeria, many researchers have decried the perceived low level of enrolment in science, especially in the secondary schools (Aina \& Akanbi, 2013; Akanbi, 2003). Akanbi (2003) observed that the trend in the enrolment and performance of senior secondary school students in science related subjects, especially physics, has assumed threatening and frightening dimensions, with students' lack of interest in physics associated to the preconceived idea that physics is difficult.

Reports of low enrolment and attainment in physics among secondary school pupils have also been reported of other countries (see Williams, et al., 2003; Angell, et al., 2004). For instance, Williams et al. (2003) reported that fewer year 10 (before national exams at age 16) pupils were interested in physics than in biology in England and observed that pupils 'decreasingly see physics as able to contribute to solutions to environmental or medical problems, and increasingly see physics as requiring mathematical ability’ (p.325). Similarly, Angell et al (2004) investigated pupils' and teachers' views of physics and physics teaching in Norway and reported that "the number of physics pupils is too small to cover estimated future demands for a skilled labour force and may be also too small to ensure a sufficient number of informed citizens in a democracy" (p 702).

\section{Students' choice of post-compulsory school science and physics}

The present study is concerned about the school-based factors that affect students' enrolment in physics in secondary schools. Several studies have been conducted to investigate factors that affect students' choice of science and physics in particular at the senior secondary school level (Akpan, 1986; Stables, 1990; Breakwell \& Beardsell, 1992; Semela, 2010). For instance, Akpan (1986) investigated the effect of age, sex, attitudes to science, IQ and students' personality on choice of science subjects among secondary school students in Nigeria and reported that 'attitudes to science was the most important factor in science choice, followed by IQ' and that 'sex and personality were important to a lesser degree' (p.99). The implication is that 
students choose science as a result of their positive attitude and interest. Some studies on students' career or future choice indicate that parents are the most influential factors. Omosewo (2003) investigated variables such as parents, school counsellors, peer group, friends, relatives and self (the student) that influence choosing physics and observed that parents and school counsellors ranked as the highest influencing factors on students' choice of physics.

Another factor that has been highly debated in science, engineering and technology enrolment is that of gender. Brotman \& Moore (2008) maintained that despite effects to narrow the gender gap in these fields, "girls and women continue to be underrepresented and marginalized" (p. 971). In most under developed and developing countries, gender-defined role differentiations and beliefs are very strong even in their society and communal lifestyles. Women in such societies are often groomed early in life to be better homemakers and mothers and are encouraged to choose subjects like Home management and Music. For instance, while some (e.g. Breakwell \& Beardsell, 1992) reported that males have more positive attitudes towards choice of science, with greater levels of participation in science related extracurricular activities than females, others (e.g. Stables, 1990) did not agree that gender difference affects students' uptake of science. However, Lorenzo, Crouch \& Mazur (2006) demonstrated that gender gap in physics classroom was reduced effectively with the use of interactive teaching strategies and the understanding of both males and females were significantly increased with the use of such methods. Some research has shown that females have more negative attitudes toward science and perceive science subjects to be more useful to boys (Wasanga, 1997; Amunga, Amadala \& Musera, 2011).

The problem of low enrolment of science and particularly physics in the post-compulsory classes is not peculiar to Nigeria. The enrolment in physics at all levels of education is low in many African countries (Musasia, Abacha \& Biyoyo, 2012) and indeed in most countries of the world (Semela, 2010; Osborne, Simon, \& Collins, 2003). In South Africa for instance, Mundalamo (2006) reported the decreasing number of students who choose physics as one of their subjects. He went further to state that 'before the 1994 democratic elections, the South African physics community was dominated by whites' as 'most African pupils did not have the opportunity to choose mathematics and science as subjects at school' (p. 5). He quoted the then Minister of Education in South Africa, Naledi Pandor thus:

"Mathematics and science have for a long time been a preserve of a select few. Many generations of young people have been denied access into these important subjects because of apartheid and because of the myth that one is born either with or without an ability to handle these subjects" (p. 5). 
This raises questions about the goals of early western and missionary education to most African countries. This is despite the important position of physics as a pre-requisite to most careers and courses in Science and Technology that drive industrialization and technological breakthrough pursued by most economies of the world.

The problem of relatively fewer students choosing science and physics in particular after the post-compulsory secondary classes has also been reported in developed countries like the United States, Canada, United Kingdom and Australia (Osborne, et al., 2003; Bennett, Lubben \& HampdenThompson, 2013). Osborne, et al. (2003:1050), for instance, reported the stark nature of the decline in the numbers choosing to do three sciences at 16 for A-level, at the point of choice' in England and Wales and that 'physics has been the subject of a continuing 15-year decline in numbers enrolling and passing'(p. 1058). In 2012 for instance, the percentage of students that took ' $A$ ' levels in science subjects in the England were 8\% (Physics), 11\% (Chemistry), and 14\% (Biology) (Questions for Governors, 2014). Bennett, et al., (2013) reported a two-decade decline in A-level biology, chemistry and physics enrolment between 1990 and 2010 in England with percentages varying from 6.1 in 1990 to 3.6 in 2010. Smithers \& Robinson (2009) also reported a decline in physics uptake in Australia, Republic of Ireland, Finland, New Zealand and Scotland. However, Sparkes (1995) investigated the situation of physics enrolment and attainment in physics in England and Scotland and reported that more young pupils in Scotland take physics beyond 16 , attributing this to the fact that physics was taught by well qualified physics teachers in Scotland. A later study by Reid \& Skryabina (2002) also reported that physics was a popular subject among school pupils in Scotland, unlike many other countries. In a similar vein, Mujtaba \& Reiss (2013) reported that in UK, 'the number of students entering physics A-Level has begun to see a rise over the past five years, having reached a low in 2006' (p.2980). Smithers \& Robinson (2008) reported that 'physics has been in steep decline in schools in England, particularly in comprehensive schools. But that there are some schools in which physics is thriving' (p.49). Their work attempted to draw some lessons in schools where physics was 'thriving', what they did right, and to see if the trend can be reversed in schools with general decline when those principles are applied. Mullis, Martin, Robitaille \& Foy (2009) in their international report of the Trends In Mathematics and Science Study (TIMSS) conducted in 2008 observed that the percentage of students in the age cohort receiving physics was considerably low in the participating countries. In a study of under-represented minorities in High school physics in the United States, White \& Tesfaye (2010) reported that, in 2009, only $25 \%$ of Black and Hispanic high school students in the U.S. took at least one physics course prior to graduation, which was well below the enrolment of white and Asian 
students with $41 \%$ and $52 \%$ respectively. They attributed the differences more to socioeconomic than racial factors.

The "worrying decline in the uptake of physics by students at secondary level" in Australia necessitated the Physics decadal plan of the Australian Academy of Science in December 2012 (Australian Academy of Science 2012, p.vii). The plan was a presentation of the Australian physics community's strategic vision for the ten years of 2012-2021. Dekkers \& Laeter (2001) acknowledged the significant contribution of the scientific community in Australia to primary and secondary level science education. They noted that the scientific community through the Australian Academy of Science has ensured that

"science education features prominently in schooling and that curricula are appropriate and relevant' with the production of 'series of textbooks at both the secondary, and more recently at the primary level, to provide up-to-date and educationally sound science educational materials to the school system" (p.488).

The effort by the Australian Academy of science to popularize physics and increase the uptake of the subject by school pupils is worthy of commendation and emulation. Considering the relevance of physics as the heart of science and technology with its undisputable contributions in the fields of medicine, information technology, space science and industrial revolution, it is hoped that much more can be achieved when countries make conscientious efforts to popularize and strengthen the study of physics especially at the primary and secondary levels of education. While most developed countries are towing this line, much is not yet done especially in most African countries to match words with action.

\section{Explanations for decline in physics uptake among secondary school students}

A concern for the low on enrolment in physics among secondary school students, along with school-factors that may affect it, is a key focus in the present study. Subsequently, relevant literature on possible explanations for the low uptake is included here, in an attempt to establish the status quo, to contextualize physics enrolment issues from different countries with their particular school systems, and to provide good basis for the discussion of the findings.

Several studies have reported that students' perception of physics as a difficult subject, teachers poor pedagogical content knowledge, the nature of the subjects are major reasons for the low uptake of the subject (Keller, et al., 2017; Bennett, et al., 2013). Aina \& Akanbi (2013) studied the perceived causes of students' low enrolment in science in Nigerian secondary schools and reported a lack of qualified teachers, motivation, instructional materials, 
nature of the subject, and low students' interest among factors that cause low enrolment. In particular, they reported that 'Physics is too abstract, biology is too wide in scope, chemistry is very hard to learn and science is too mathematical' ( $p$ 20). Semela (2010) investigated the factors influencing the choice of physics in Ethiopia and reported among others that weak mathematics background, poor teacher qualification and pedagogical content knowledge were reasons for the low enrolment of students for physics.

The reasons or explanations for the low physics enrolment after postcompulsory schooling in developed countries are not different. Williams, et al. (2003) investigated why secondary school students (in the UK) are not interested in physics and reported that 'the most obvious factor raised by students was the link between finding a subject boring and perceiving it as being difficult' ( $p$ 329). From the foregoing, common factors from literature that result in low enrolment and lack of interest in physics can be summarized to include the perceived nature of the subject, lack of qualified physics teachers, lack of self-confidence and perceived future irrelevance of the subject. Recognizing the relevance of physics and the key role it plays in careers driving a fast-developing scientific world with breakthroughs in medical science, space technology, agriculture and food technology, it is important to identify by research and implement workable policies that would encourage young people to develop positive interest in the study of physics at all levels.

\section{Research Questions}

Two main research questions were designed to guide the study:

1. What is the level of student enrolment for physics in secondary schools in Nigeria?

2. What school-based factors are responsible for the enrolment, teaching and learning of physics in secondary schools in Rivers State, Nigeria?

\section{Methodology}

This study made use of mixed methods, 'a procedure for collecting, analysing, and "mixing" both quantitative and qualitative methods in a single study or a series of studies to understand a research problem' (Creswell, 2012, p.535). This approach has been chosen to generate an in-depth understanding of the research topic with the collection of data in varied forms presenting a comprehensive picture of the issues under investigation. Particularly, this research adopted the descriptive survey together with the case study design. As a survey, questionnaires were used to obtain information from schools in the area of study. Interviews with physics teachers and focused group discussions involving both physics and non-physics students were also carried out. 


\section{Sample and Sampling Technique}

The study was conducted in Rivers State, Nigeria. Rivers State is one of the major oil producing States in the oil-rich Niger Delta region of Nigeria. Because of the oil producing status of the state, all the oil and gas exploration and producing companies have their offices in Rivers State. Its capital, Port Harcourt is the fifth most populous city in Nigeria. Purposive sampling was utilized to select 8 schools in the high and low performing local government areas of the state in physics having a boy, girl and co-educational school. The schools are in 3 of the 24 local government areas of the state. This school selection criteria were adopted to capture the three school types in the system and, to explore the possibility of interesting outcomes of gender and physics enrolment. Schools located in areas where students obtain lower grades in physics (Zone 1), higher grades (Zone 2) and a specialist science college with high attainment records (SC) were involved in the study. In all, 14 physics teachers, 248 physics students and 116 non-physics students participated in the study.

\section{The Questionnaires}

Three questionnaires were developed for use in the study Questionnaire for Physics Teachers (QPT), Questionnaire for Physics Students (QPS) and the Questionnaire for Non-Physics Students (QNPS). The Questionnaire for Physics Teachers (QPT) is a 22-item instrument that fielded questions about the school, teacher characteristics and qualification, availability and utilization of resources for teaching Physics, teachers' professional training and activities in the school and the school climate which have been identified in literature to have some effect on students' enrolment (Williams, et al, 2003). The Questionnaire for Physics Students (QPS) is a 12item instrument that seeks to elicit information about the school, students' choice of physics, students' experiences in physics classrooms, their perception about their physics teacher and their school climate. The Questionnaire for Non-Physics Students (QNPS) is a One-page 5-item questionnaire intended to elicit information from non-physics students on their experiences in science classes during the compulsory years of schooling, which might have informed their decision not to choose physics.

\section{Interviews/Focus Groups}

Two semi-structured interview schedules were used for this study The Interview Schedule for Teachers (ISfT) and the Interview Schedule for Students (ISfS). The ISfT is made up of 9 questions and lasted between 4560 minutes, while the ISfS composed of 8 questions lasted between 25 45 minutes. All questions on the schedules (ISfT and ISfS) were consistent with the research questions and developed by the researcher from an extensive 
search of the literature on possible school-based factors that could influence students' enrolment in physics. For instance, on school-based factors that affect enrolment, teaching and learning (RQ2), teachers were asked if there were factors that hindered or incapacitated effective teaching and learning of physics in their schools. Teachers' responses were appropriately followed up with prompts and probes. The interviews also focused on teaching strategies, resource utilization and views about students' engagement and attainment. In each of the eight schools, quota sampling was used to select five students of high, average and low abilities to constitute the focus group. Two of the five students were non-physics students. All senior physics teachers in each school were purposively selected, and participated in the teachers' interviews.

\section{Findings}

Secondary and primary data obtained from the schools are presented. Table 1 shows the enrolment of students in the senior secondary school certificate examination in the science subjects in Nigeria from $2004-2013$. Table 2 is the enrolment of students for the Senior School Certificate Examination (SSCE) in biology, chemistry and physics for 10 years in Rivers State, located in the southern part of Nigeria.

Table 1: SSCE enrolment in science subjects in Nigeria

\begin{tabular}{ccccc}
\hline Year & $\begin{array}{c}\text { Total } \\
\text { SSCE } \\
\text { Enrolment }\end{array}$ & $\begin{array}{c}\text { Biology } \\
\text { Enrolment }\end{array}$ & $\begin{array}{c}\text { Chemistry } \\
\text { Enrolment }\end{array}$ & $\begin{array}{c}\text { Physics } \\
\text { Enrolment }\end{array}$ \\
\hline 2004 & 1051246 & 99.4 & 32.4 & 31.8 \\
2005 & 1091763 & 99.4 & 33.1 & 32.6 \\
2006 & 1184223 & 99.3 & 33.3 & 18.7 \\
2007 & 1275330 & 99.4 & 34.1 & 33.3 \\
2008 & 1369142 & 99.4 & 34.2 & 33.9 \\
2009 & 1373009 & 99.3 & 34.8 & 34.6 \\
2010 & 1351557 & 99.3 & 35.8 & 35.6 \\
2011 & 1540250 & 99.4 & 37.3 & 37.1 \\
2012 & 1695878 & 99.4 & 37.8 & 37.6 \\
2013 & 1689188 & 99.4 & 38.5 & 38.3 \\
\multicolumn{2}{c}{ Average } & 99.4 & 35.1 & 33.4 \\
\hline
\end{tabular}

(Source: West African Examinations Council, Lagos, Nigeria) 
Table 2: SSCE enrolment in Science subjects in Rivers State

\begin{tabular}{|c|c|c|c|c|}
\hline \multirow[t]{3}{*}{ Year } & \multirow{3}{*}{$\begin{array}{l}\text { Total SSCE } \\
\text { Enrolment }\end{array}$} & Biology & Chemistry & Physics \\
\hline & & $\%$ & $\%$ & $\%$ \\
\hline & & Enrolment & Enrolment & Enrolment \\
\hline 2004 & 66,358 & 98.6 & 42.1 & 40.6 \\
\hline 2005 & 72,229 & 99.0 & 43.1 & 41.5 \\
\hline 2006 & 76,594 & 98.9 & 43.5 & 42.5 \\
\hline 2007 & 87.004 & 99.0 & 43.8 & 42.9 \\
\hline 2008 & 99,271 & 99.2 & 43.3 & 42.5 \\
\hline 2009 & 81,618 & 99.3 & 44.4 & 43.5 \\
\hline 2010 & 43.757 & 98.6 & 47.3 & 46.7 \\
\hline 2011 & 61,429 & 99.4 & 46.3 & 45.9 \\
\hline 2012 & 60,654 & 98.6 & 46.1 & 45.7 \\
\hline 2013 & 65688 & 99.5 & 46.7 & 46.4 \\
\hline & Average & 99.0 & 44.7 & 43.8 \\
\hline
\end{tabular}

Table 1 shows that only an average of $33.4 \%$ of students enrolled for the SSCE chose physics. Chemistry is also seen as not popular among students with an average enrolment of $35.1 \%$, while Biology with an average enrolment of 99.4\% appears to be the most popular and chosen science subject at the end of post compulsory education in Nigeria. Similarly, Table 2 shows that for same period in Rivers State, physics was the least chosen science subject with an average of $43.8 \%$. The trend of enrolment is shown as a graph in Figure 1.

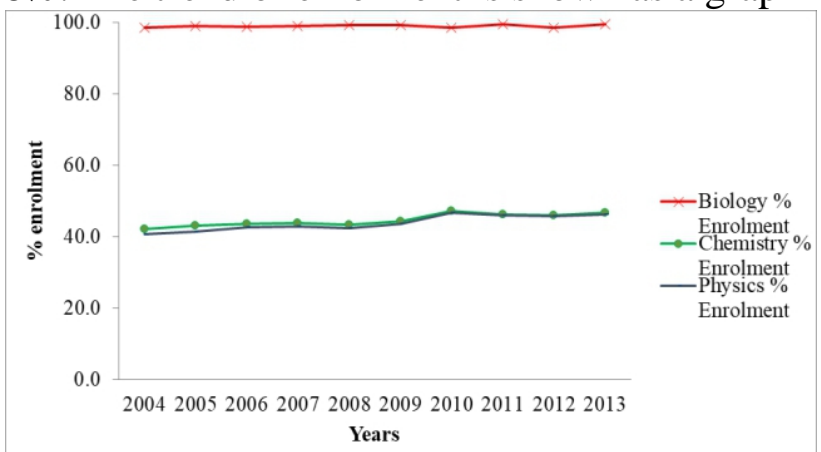

Figure 1: Enrolment trend of science enrolment, Rivers State 2004-2013

The percentage of physics students in the participating schools was also obtained and presented in Table 3. 
Table 3: Total SSS 3 and physics enrolment in sampled schools

\begin{tabular}{ccccc}
\hline Zones & Schools & $\begin{array}{c}\text { Total } \\
\text { Enrolment }\end{array}$ & $\begin{array}{c}\text { No of physics } \\
\text { students }\end{array}$ & Percentage \\
\hline \multirow{5}{*}{ Zone 1} & $\mathrm{~A}$ & 26 & 9 & 34.6 \\
& $\mathrm{~B}$ & 36 & 15 & 41.7 \\
& $\mathrm{C}$ & 72 & 12 & 16.7 \\
& $\mathrm{D}$ & 31 & 10 & 32.3 \\
\hline \multirow{3}{*}{ Zone 2 } & $\mathrm{A}$ & 116 & 50 & 43.1 \\
& $\mathrm{~B}$ & 249 & 72 & 28.9 \\
\hline SC & $\mathrm{C}$ & 98 & 35 & 35.7 \\
\hline
\end{tabular}

The data as shown in Table 3 reveal that physics enrolment in all schools involved in the study, except in school C1 (16.7\%), B2 (28.9\%) and SC $(100 \%)$, were around the national and state enrolment figures as shown in Tables 1and 2. All students in SC compulsorily choose physics, as the school only admits science-focused students. Figure 2 is a chart showing the number of physics students relative to the total number of students in the final class of secondary education in participating schools.

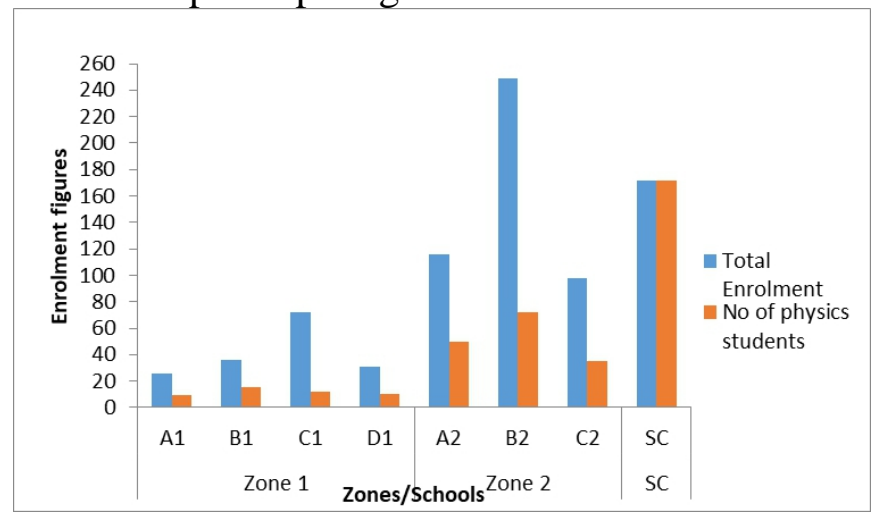

Figure 2: Physics/total enrolment in participating schools

\section{Perception of the state of facilities for the teaching and learning of physics and effect on enrolment}

Data from the questionnaire for physics students is presented in Table 4. Teachers' questionnaire response on the extent of availability of teaching and learning facilities in core areas of the physics curriculum in Nigeria are presented in Table 5. Qualitative data from teachers and focus group interviews are also presented. 
Table 4: Students' response: "My school has enough facilities for conducting investigations in physics"

\begin{tabular}{lll}
\hline Responses & Frequency & Percent \\
\hline Strongly Agree & 10 & 4.0 \\
Agree & 50 & 20.2 \\
Disagree & 71 & 28.6 \\
Strongly Disagree & 90 & 36.3 \\
Can't say & 21 & 8.5 \\
\hline
\end{tabular}

Table 4 shows that, only about $25 \%$ of the students agree that their school has enough facilities for conducting experiments or investigations in physics. Of this number, about $62 \%$ are from the SC school.

Table 5: Teachers' response on the availability of resources for teaching and learning of core topic areas in physics

\begin{tabular}{|c|c|c|c|c|c|}
\hline \multirow[b]{2}{*}{ Response } & \multicolumn{5}{|c|}{ Core topic areas (\% respondents) } \\
\hline & $\begin{array}{l}\text { Interaction of } \\
\text { matter, space } \\
\text { and time }\end{array}$ & $\begin{array}{l}\text { Conservation } \\
\text { principles }\end{array}$ & $\begin{array}{l}\text { Fields at } \\
\text { rest and in } \\
\text { motion }\end{array}$ & $\begin{array}{l}\text { Energy } \\
\text { quantization and } \\
\text { duality of matter }\end{array}$ & $\begin{array}{l}\text { Wave motion without } \\
\text { material transfer }\end{array}$ \\
\hline Don't Have & 21.4 & 42.9 & 35.7 & 71.4 & 35.7 \\
\hline Don't Have & & & & & \\
\hline $\begin{array}{l}\text { Enough } \\
\text { Have }\end{array}$ & 64.3 & 50 & 50 & 28.6 & 57.1 \\
\hline Enough & 14.3 & 7.1 & 14.3 & 0 & 7.1 \\
\hline
\end{tabular}

Table 5 indicates that most of the teachers were of the opinion that their schools do not have enough facilities for teaching and learning in physics with only $14.3 \%$ claiming to 'have enough' in only two of the five core areas of the physics curriculum.

Both students and teachers expressed the effect of the poor state of teaching and learning facilities. All students in their focus discussions in 6 out of the 8 schools were unanimous in their position that facilities for the teaching and learning of physics in their schools were inadequate and that this was a factor in students' dislike of the subject. For instance, in one school, the students maintained that

"I think that why some students are not serious with physics is because... the equipment that the school need to provide for the physics practical ... and the ones that are there are not good... the equipment for us to praticalize are not there..."

Similar views were expressed in another school when a student who was frustrated to drop-out of the physics class stated that:

“...as for me, I never love the subject and I see the subject as a boring subject, I don't even like how they are teaching it... in our school here, we don't normally use to do practical..." 
There seem to be a consistency among both teachers and students that their schools had a dearth of adequate resources for teaching and learning of physics. According to one of the teachers,

"Government is not doing well in that area. They only come out with tools for carrying out practical whenever WAEC is coming, and after that nothing is being done again".

On laboratory activities in the teaching and learning of physics, the students in one of the schools revealed that they did not have such sessions in school and that they individually seek help outside the school.

"we don't use to do it (practical) unless individually, you go out to search for some help, but if it is in this school, we don't have anything like that'.

The teacher in the same school also alluded to the fact that the school lacked basic resources for the teaching and learning of physics.

"...where there is no standard facility - like here, they are

not accessible to computer, so what we always do is the chalk-board method ..."

About $79 \%$ of teachers who were interviewed agreed that the poor state of facilities do not encourage young pupils to choose physics and science subjects in general after the compulsory years of secondary education. For instance, one teacher said:

"the challenge we are having here is actually ... apparatus to perform practical, students have an interest but due to lack of instruments, some of them are not interested in it"

Explaining further, the physics teacher maintained that,

"Well, in my school we lack so many things, we don't have anything like online resources, computer; we don't have light here so you cannot do something on electricity"

The situation of resource availability is however different in the SC. According to the senior physics teacher in the school,

"As far as SC is concerned, we have enough material resources. In addition, we also have an e-library with all the facilities that the students can access for whatever materials they need, we laboratories -enough apparatus to demonstrate at this level"

\section{Effect of teacher, pedagogical approaches and the nature of physics on} student enrolment

Some students also revealed teachers' truancy and teacher shortages, and connected these to the low popularity of physics among students. 
"... some are not serious... like a term, he will just come twice or thrice... you know you have a class to teach, you will be absent"

One of the non-physics students said she would have been a science student but for the lack of teachers in the subjects:

"I wanted to be a science student, but we did not have physics and chemistry teachers so I decided to go for the arts"

The quotes above suggest that students are of the opinion that teacher-factors also affect the enrolment of students in physics. On a positive note, all students in one school were full of praise for the teacher and that he was a main factor for their choice of physics.

"I choose to be a physics student because of the teacher ...

he makes everything easy and interesting"

Apart from teacher and resource related reasons, students also gave some insight on the reasons for the least popularity of physics, compared to biology. According to some students, the nature of physics, lack of relevance of most physics concepts to everyday life and the perceived difficulty level of physics as opposed to the practical nature of biology are reasons for the more popularity of biology. For instance, the position of most non-physics students when asked the reasons for their preference for biology to physics is captured in the expression of this student:

"I love studying what I can apply. I don't find physics something that can become practical, like a topic we learnt in physics, in SS II ... we learnt about equilibrium of forces ... it's all drawing, I can't apply it, but in biology you know about your body, you know how things happen".

The response of this student would suggest that she finds it difficult to relate the lessons in physics class to practical occurrences around her. The student could not unfortunately match the force diagrams drawn on paper with materials and objects that demonstrate the equilibrium of forces in nature. Cairns (2019) reported that students obtained better achievement scores when they carried out experiments in the labs, as that deepens their understanding of theoretical concepts that are taught during lessons.

\section{School-based factors affecting student enrolment}

Teachers' responses on main school-based factors that affect students' choice of physics presented in Table 6 . The result shows that lack of adequate number of qualified physics teachers, teaching physics by theory, lack of lab equipment and lack of career guidance/counselling services are all schoolrelated factors that affect students' choice of physics. 
Table 6: Teachers' opinion on main school-related factors affecting students' choice of physics

\begin{tabular}{lcccccc}
\hline & $\begin{array}{c}\text { Strongly } \\
\text { Agree }\end{array}$ & Agree & Disagree & $\begin{array}{c}\text { Strongly } \\
\text { disagree }\end{array}$ & $\begin{array}{c}\text { Can't } \\
\text { say }\end{array}$ & Total \\
\hline $\begin{array}{l}\text { Lack of adequate number qualified physics } \\
\text { Teachers }\end{array}$ & $7(50.0)$ & $1(7.1)$ & $2(14.3)$ & $3(21.4)$ & $1(7.1)$ & 14 \\
Teaching physics by theory without practical & $4(28.6)$ & $5(35.7)$ & $3(21.4)$ & $1(7.1)$ & $1(7.1)$ & 14 \\
Lack of lab equipment for demo/experiments & $7(50.0)$ & $2(14.3)$ & $1(7.1)$ & $4(28.6)$ & $0(0)$ & 14 \\
Lack of career guidance/counselling services & $8(61.5)$ & $5(38.5)$ & $0(0)$ & $0(0)$ & $0(0)$ & 13 \\
Unsocial lifestyle of some physics teachers & $2(14.3)$ & $3(21.4)$ & $3(21.4)$ & $4(28.6)$ & $2(14.3)$ & 14 \\
\hline
\end{tabular}

\section{Gender and enrolment}

The percentage of enrolled physics students by gender was computed for the 8 schools and correlated with teacher and resource factors, and result presented in Table 7.

Table 7: Spearman rho's Correlation of Students' Enrolment with Teacher and Resource Factors

\begin{tabular}{|c|c|c|c|c|c|}
\hline & & $\begin{array}{l}\text { Teacher } \\
\text { Qualification }\end{array}$ & $\begin{array}{l}\text { Teaching } \\
\text { experience }\end{array}$ & $\begin{array}{l}\text { Resource } \\
\text { availability } \\
\text { index }\end{array}$ & $\begin{array}{l}\text { Resource } \\
\text { utilization } \\
\text { index }\end{array}$ \\
\hline \multirow{3}{*}{$\begin{array}{l}\% \text { of total } \\
\text { students in SS3 } \\
\text { enrolled for } \\
\text { physics }\end{array}$} & $\begin{array}{l}\text { Spearman } \\
\text { rho's } \\
\text { correlation }\end{array}$ & .346 & .038 & -.024 & .157 \\
\hline & Sig. (2-tailed) & .401 & .928 & .955 & .711 \\
\hline & $\mathrm{N}$ & 8 & 8 & 8 & \\
\hline
\end{tabular}

The result shows low positive correlations between students' enrolment in physics and teacher qualification, teaching experience and resource utilization, which were however not statistically significant with all p-values $>0.05$. Also, no significant correlations was found between male or female physics students' enrolment with teacher qualification, teaching experience, resource availability index and resource utilization index as shown in Tables 8 and 9.

Table 8: Correlation of male students' enrolment with teacher and resource factors

\begin{tabular}{lllll} 
& $\begin{array}{l}\text { Teacher } \\
\text { Qualification }\end{array}$ & $\begin{array}{l}\text { Teaching } \\
\text { experience }\end{array}$ & $\begin{array}{l}\text { Resource } \\
\text { availability } \\
\text { index }\end{array}$ & $\begin{array}{l}\text { Resource } \\
\text { utilization } \\
\text { index }\end{array}$ \\
\hline $\begin{array}{l}\text { Spearman rho's } \\
\text { Correlation }\end{array}$ & .031 & -.735 & -.145 & -.224 \\
Sig. (2-tailed) & .953 & .096 & .784 & .670 \\
N & 6 & 6 & 6 & 6 \\
\hline
\end{tabular}


Table 9: Correlation of female students' enrolment with teacher and resource factors

\begin{tabular}{lllll}
\hline & $\begin{array}{l}\text { Teacher } \\
\text { Qualification }\end{array}$ & $\begin{array}{l}\text { Teaching } \\
\text { experience }\end{array}$ & $\begin{array}{l}\text { Resource } \\
\text { availability } \\
\text { index }\end{array}$ & $\begin{array}{l}\text { Resource } \\
\text { utilization } \\
\text { index }\end{array}$ \\
\hline $\begin{array}{l}\text { Spearman rho's } \\
\text { Correlation }\end{array}$ & -.243 & -.441 & .348 & .265 \\
Sig. (2-tailed) & .643 & .381 & .499 & .612 \\
$\mathrm{~N}$ & 6 & 6 & 6 & 6 \\
\hline
\end{tabular}

It is likely that the small $(n=8)$ sample size of schools may have affected the correlations. However, data from both students' interviews (section 3.2 and Table 4) and teachers (Tables 5 and 6) suggests that lack of adequate number of physics teachers, teaching methods, lack of equipment, and lack of career guidance/counselling services affect students' enrolment.

\section{Discussion of findings}

The enrolment data of students in science for 10 years (2004-2013) in Nigeria is shown in Tables 1 and 2. On students' enrolment for physics in Nigeria, the finding of this study suggests that there is a relative low level of students' enrolment for physics (compared to biology and chemistry) after the compulsory years of secondary education in Nigeria. Also, the study found that students prefer to choose biology to physics as a result of the nature of physics, perceived lack of relevance of most physics concepts to everyday life, perceived difficulty of physics compared to biology and the practical nature of biology. Findings from the study also suggest that the low popularity of physics among students in Nigeria is as a result of 'lack of qualified physics teachers', 'teaching physics by theory without practical work', 'lack of laboratory equipment for demonstration/experimentation' and 'lack of guidance/counselling services'. These findings are discussed below.

The data as shown in Table 1 reveals that nationally, an average of $33.4 \%$ of students enrolled for physics at the senior secondary school certificate level. Chemistry had an average enrolment of $35.1 \%$ while biology had as high as $99.4 \%$ enrolment on the average. Interestingly, these enrolment figures are considerably higher than those for England (Questions for Governors, 2014; Bennett, et al., 2013). With the poor provision of welfare and social services by government, the relatively higher science uptake in Nigeria may be explained by the desire of young people to gain employment in oil and gas industries, where workers are outlandishly paid than every other employment, with oil being the mainstay of the Nigerian economy. Most Nigerians would struggle to get well-paid jobs in these sectors without these qualifications. This assumption agrees with the report by James (2007, p.9) that "university course and career requirements have most influence on students' choices" of experimental science subjects. 
As observed, nearly $100 \%$ of students enrol for biology both nationally and in the state. The National policy on Education in Nigeria before that of 2013, made it compulsory for students to choose at least one science subject (FRN, 2004). Although the National Policy on Education for Nigeria did not specifically justify the compulsion of students' choice of a science subject, it is thought that that is the government's effort to encourage scientific literacy among its populace.

On the preference of students for biology to physics, students involved in this study have attributed the reason to the nature of physics, perceived lack of relevance of most physics concepts to everyday life, perceived difficulty of physics compared to biology and the practical nature of biology. These findings are consistent with the findings of some other researchers (see Keller, et al., 2017). For instance, Williams, et al. (2003) reported that students perceive biology to be an interesting subject whereas physics is perceived as boring while Lyons (2006) reported that most students in Australia perceived Junior high school science as irrelevant, difficult and uninteresting. The link of students' interest and perception of the difficulty level of a subject to the choices they make at the post compulsory stage of education is significant as studies have shown that what students find interesting and understandable, they learn best and tend to choose for further studies (Williams et al., 2003; Norris, Morris \& Lummis, 2018). Norris, et al., (2018:2305) reported that 'enthusiastic/successful groups have higher efficacy compared to disinterested/fearful groups'.

On school-based factors that affect physics enrolment, responses of both students and teachers indicate that 'lack of adequate number of qualified physics teachers', 'teaching physics by theory without practical work', 'lack of laboratory equipment for demonstration/experimentation' and 'lack of guidance/counselling services' were the main school-based factors that discourage students from choosing physics after compulsory years of schooling. The finding of this present study agrees with that of Aina and Akanbi (2013) and Erinosho (2013), who reported that lack of qualified teachers and instructional materials were some reasons why the enrolment of students for physics was low in Nigeria. The finding of this study is also consistent with that of Semela (2010), who reported that poor teacher qualification and pedagogical content knowledge were some reasons cited by students why few students choose physics. Also, in the UK, Williams et al. (2003) reported that physics is generally perceived to be difficult and irrelevant. Although the perception of difficulty and irrelevance of the subject by students is not overtly a school-based factor, teachers have a role in presenting the content of physics with applications and illustrations relevant to the everyday experiences of learners in the environment. Williams et al. (2003) suggested that to encourage more participation in physics, teachers 
should "extend the way in which they exemplify less popular areas of physics by reference to the more popular" (p 327). For instance, their study also reported topics in physics that students find boring such as 'forces' and others that the students find interesting such as 'space'. They suggested that teachers present physics content as relevant and interesting to students. This ingenuity of seeking for ways of illustrating physics concepts with familiar experiences of the learners is what is desired of physics and science teachers to inspire students' interest in the subject. It is therefore important to identify policies and strategies engaged in by government and concerned agencies on the popularization of not only physics but generally science education among the student populace so as to ensure a more science literate society.

\section{Implications for policy and planning}

The findings of the present research indicate that students' enrolment in physics is low in Nigeria, relative to biology and chemistry. The implication of this finding is that physics is the least popular science subject among secondary school students in Nigeria. Considering the relevance of physics in national and technological development, it is important that policy makers device ways of popularizing the study of physics. This can be done by providing adequately qualified physics teachers, provision of Continuing Professional Development, CPD for physics teachers and making the study of science compulsory in schools by designing a 'science for art' module of physics, chemistry and biology for the art students. Similarly, the finding of this study on the students' perception of the nature of physics and the lack of relevance of most physics ideas to students' experiences has implications for curriculum developers and policy makers. The finding implies that students are more likely to choose physics if the content is presented in concrete and illustrative ways that connect physics ideas with the everyday experiences of the students. This is very important especially in developing countries with less resources availability.

Secondly, the findings that lack of adequate number of qualified physics teachers, lab equipment for demonstration and experimentation, and guidance/counselling services affect the enrolment of students for physics have implications for policy, planning and institutions involved in Initial Teacher Education (ITE) especially in developing countries. They are to ensure that quality teachers are recruited and retained in public schools, possibly by enhancing their wages and welfare packages with ample opportunities for training and re-training on the job. It is also important that developing countries consider the funding of science education with adequate provision of laboratory facilities for the teaching and learning of science, especially during the compulsory years of schooling. 


\section{Conclusion}

From the foregoing, it is therefore important to identify policies and strategies to popularize physics and secondary science to ensure a more science literate society in developing countries. In this regard, the model in China where physics is made compulsory up to year 11 with a specialized 'physics for art' course (see Zhu, 2008) for the non-science students is worthy of emulation. This would help to prepare young people to be equipped with scientific and technological skills and knowledge to drive the growth of developing countries. Another model that should be considered for possible emulation and trial is the 'physics decadal plan' proposed by the Australian Academy of Science for the Australian government. The plan was a strategic vision for ten years from 2012 to 2021 , with the goal of increasing the physics community in Australia, achieve a physics literate work force, attract and retain pupils into physics at all levels of education and the use of physics evidence base to inform the development of relevant policies in the country. It is hoped that if students were encouraged to take up physics at secondary, college, graduate and postgraduate levels with appropriate motivation and encouragement, the much-needed quality physics teachers would be readily supplied to the school system; they would further inspire and motivate young pupils to choose the subject in post compulsory years.

\section{References:}

1. Aina, J.K. \& Akanbi, A.G. (2013). Perceived causes of students' low enrolment in science in secondary schools, Nigeria. International Journal of Secondary Education, 1(5), 18-22.

2. Akanbi A.O. (2003). Trend in physics education in secondary schools in Kwara State. Lafiagi Journal of science education, 5(1\& 2), 69- 75.

3. Akpan, E.U.U. (1986). Factors affecting students' choice of science subjects in Nigerian secondary schools. Research in Science \& Technological Education, 4(1), 99-109.

4. Amunga, J. K., Amadalo, M. M., \& Musera, G. (2011). Disparities in chemistry and biology achievement in secondary schools: Implications for vision 2030. International Journal of Humanities and Social Science. 1(18), 226-236.

5. Angell, C., Guttersrud, O., Henriksen, E.K. \& Isnes, A. (2004). Physics: Frightful, But Fun Pupils' and Teachers' Views of Physics and Physics Teaching. Science education, 88(5), 683-706.

6. Australian Academy of Science (2012). Physics Decadal Plan 2012 2021: Building on Excellence in Physics, Underpinning Australia's Future. Retrieved on 08/08/2014 at http://www.utas.edu.au

7. Bennett, J., Lubben, F. \& Hampden-Thompson, G. (2013). Schools that make a difference to post-compulsory uptake of physical science 
subjects: some comparative case studies in England. International Journal of Science Education, 35(4), 663-689.

8. Breakwell, G. M. \& Beardsell, S. (1992). Gender, parental and peer influences upon science attitudes and activities. Public Understanding of Science, 1, 183-197.

9. Brotman, J.S. \& Moore, F.M. (2008). Girls and Science: A review of four themes in the science education literature. Journal of Research in Science Teaching, 49(9), 971-1002.

10. Cairns, D. (2019). Investigating the relationship between instructional practices and science achievement in an inquiry-based learning environment. International Journal of Humanities and Social Science, 41(15), 2113-2135.

11. Creswell, J.W (2012). Educational Research: Planning, Conducting, and Evaluating Quantitative and Qualitative Research. 4th Boston: Pearson Education, Inc.

12. Dekkers, J., \& Laeter, J. (2001). Enrolment trends in school science education in Australia. International Journal of Science Education, 23(5), 487-500.

13. Erinosho, S.Y. (2013). How Do Students Perceive the Difficulty of Physics in Secondary School? An Exploratory Study in Nigeria. International Journal for Cross-Disciplinary Subjects in Education(IJCDSE).3(3), 1510 - 1515.

14. Federal Ministry of Education, FME (2009). National physics curriculum for senior secondary schools: Abuja: Nigerian Educational Research and Development Council.

15. Federal Republic of Nigeria (2004). National policy on Education. 4th edition, Yaba, Lagos: NERDC press.

16. Freedman, R. A. (1996). Challenges in Teaching and Learning Introductory Physics. In B. Cabrera, H. Gutfreund \& V. Kresin, (Eds.), From High Temperature Superconductivity to Microminiature (313322). New York: Plenum Press.

17. James, K. (2007). Factors influencing students' choice(s) of experimental science subjects within the international Baccalaureate Diploma Programme. Journal of Research in International Education.6(1), 9-39.

18. Keller, M.M., Neumann, K. \& Fischer, H.E. (2017). The impact of physics teachers' pedagogical content knowledge and motivation on students' achievement and interest. Journal of Research in Science Teaching, 54(5), 586-614.

19. Lorenzo, M., Crouch, C.H. \& Mazur, E. (2006). Reducing the gender gap in physics classroom. American Journal of Physics,74(2), 118122. 
20. Lyons, T. (2006). The Puzzle of Falling Enrolments in Physics and Chemistry Courses: Putting Some Pieces Together. Research in Science Education, 36,285-311.

21. Lyons, T. \& Quinn, F. (2010). Choosing Science: Understanding the declines in senior high school science enrolments. National Centre of Science, ICT and Mathematics Education for Rural and Regional Australia, viewed 29 July 2014, http://apo.org.au/node/20912

22. McCall, R. P. (2007). Relevance of Physics to the Pharmacy Major. American Journal of Pharmaceutical Education: 71(4), Article 70, 1-7.

23. Mujtaba, T \& Reiss, M.J. (2013). What Sort of Girl Wants to Study Physics After the Age of 16? Findings from a Large-scale UK Survey. International Journal of Science Education, 35(17). 2979-2998.

24. Mullis, I.V.S., Martin, M.O., Robitaille, D.F. \& Foy, P. (2009). TIMSS Advanced 2008 International Report: Findings from IEA's Study of Achievement in Advanced Mathematics and Physics in the Final Year of Secondary School, Chestnut Hill, MA: TIMSS \& PIRLS International Study Center.

25. Mundalamo, F. J. (2006). The Influence of Foundation Physics on the Performance of Students in Physics I at several South African Universities. An unpublished PhD Thesis submitted to the University of South Africa.

26. Musasia, A.M., Abacha, O.A. \& Biyoyo, M.E. (2012). Effect of Practical Work in Physics on Girls' Performance, Attitude change and Skills acquisition in the form two-form three Secondary Schools' transition in Kenya. International Journal of Humanities and Social Science, 2(23), $151-166$.

27. Norris, C.M., Morris J.E. \& Lummis, G.W. (2018). Preservice teachers' self-efficacy to teach primary science based on 'science learner' typology. International Journal of Humanities and Social Science, 40(18), 2292-2308.

28. Ogunmade, T. O. (2005). The status and quality of secondary science teaching and learning in Lagos State, Nigeria. Unpublished $\mathrm{PhD}$ thesis, Edith Cowan University, Australia. Retrieved from http://ro.ecu.edu.au.

29. Omosewo, E.O. (2003). Factors influencing Female Students' choice of Physics in Selected Secondary Schools in Ilorin Metropolis. Journal of Studies in Education, 1(5), 131 - 140.

30. Osborne, J., Simon, S. \& Collins, S. (2003). Attitudes towards science: a review of the literature and its implications. International Journal of Science Education, 25(9), 1049-1079.

31. Questions for Governors (2014). What proportion of students choose to continue each of the sciences (physics, chemistry and biology) and 
maths at A level? Retrieved online on 08/12/2014 at http://www.questionsforgovernors.co.uk

32. Reid, N. \& Skryabina, E. A. (2002). Attitudes towards Physics. Research in Science \& Technological Education, 20(1), 67-81.

33. Semela, T. (2010). Who is joining physics and why? Factors influencing the choice of physics among Ethiopian university students. International Journal of Environmental \& Science Education. 5(3), 319 -340 .

34. Smithers, A. \& Robinson, P. (2009). Physics Participation and Policies: Lessons from Abroad Buckingham: Carmichael Press.

35. Sparkes, R. A. (1995). No problem here! The supply of physics teachers in Scotland. The Curriculum Journal, 6, 101 - 113.

36. Stables, A. (1990). Differences between pupils from mixed and singlesex schools in their enjoyment of school subjects and in their attitude to science and to school. Educational Review, 42 (3), 221-230.

37. Wasanga, C. M. (1997). The attitude towards science among primary and secondary school students in Kenya. Nairobi: Academy of science publishers.

38. White, S. \& Tesfaye, C.L. (2010). High School Physics Courses \& Enrollments: Results from the 2008-2009 Nationwide Survey of High School Physics Teachers. Downloaded online on 29/07/2014 at http://www.aip.org/statistics/reports/high-school-physics-coursesenrollments

39. Williams, C., Stanisstreet, M., Spall, K., Boyes, E.\& Dickson, D. (2003). Why aren't secondary students interested in physics? Physics Education, 38(4), $324-329$.

40. Zhu, Z. (2008). A Comparison Study of Students' Reasons for Taking Physics between Two Australian High Schools and Two Chinese High Schools. Paper presented at the Australian Association for Research in Education held at Brisbane 